\title{
Infectious disease and federalism in early twentieth-century Brazil
}

\author{
Doenças infecciosas e federalismo no \\ Brasil do início do século XX
}

\author{
Eve Buckley \\ University of Delaware. \\ Newark - DE - USA \\ ebuckley@udel.edu
}

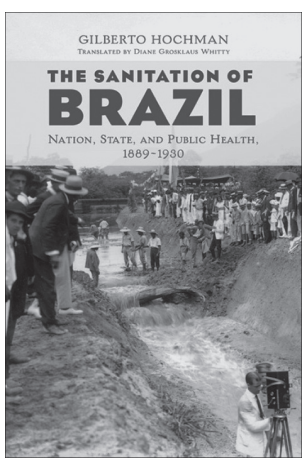

HOCHMAN, Gilberto. The sanitation of Brazil: nation, state, and public health, 1889-1930. Trans. Diane Grosklaus Whitty. Urbana: University of Illinois Press. 2016. 232p.
$\mathrm{T}$ he first edition of this book, published in 1998, introduced readers to Hochman's argument that public health concerns were central to the expansion of Brazilian federal authority over states in the early twentieth century. Since that time, this fundamental insight has been incorporated into the historiography of Brazil's First Republic and broader narratives about Brazilian public health. This new edition has been translated fluidly into English, with some updating and minor revision to aid readers unfamiliar with the Brazilian context, but the core thesis remains: "Social protection polices arose when the elites' social consciousness converged with their material interests and they saw that benefits could be gained by collectivizing welfare" (Hochman, 2016, p.X).

Hochman's training in the social sciences is evident throughout, but particularly in the first chapter, where he provides a theoretical framework for the empirical chapters that follow. He is especially influenced by the historian Abram De Swaan and sociologist Norbert

Elias regarding the historical expansion of state powers to collectivize responsibilities for social welfare, as a result of the increasing interdependence that resulted from urbanization and related developments. In Hochman's view, an epidemic of infectious disease "constitutes a paradigm of interdependence in that it illustrates both the external effects of individual adversity that impinge on all of society as well as uncertainty about the efficacy of any individual, local remedy" (Hochman, 2016, p.7). This chapter adopts a more schematic and theoretical stance than is customary in US social history, but usefully outlines how Hochman approaches his examination of the development of Brazilian public health.

Chapters two and three trace Brazilians' "awakening to a sense of nationhood born from a newfound awareness of social interdependence fostered by disease" (Hochman, 2016, p.43). Hochman outlines the implications of anticontagionism for public health policies - a view dominant in liberal Western nations in the decades preceding widespread 
acceptance of germ theory - and the shift toward recognizing the interconnections among communities wrought by microscopic pathogens and disease vectors that followed from the insights of Pasteur, Koch, and others. In Brazil, sanitarians began to promote the expansion of government authority to address the interdependence engendered by contagious disease and intervene in the public interest. Hochman emphasizes the equation of illness with state abandonment that Brazil's most prominent public health advocates (such as Miguel Pereira, Afrânio Peixoto, Artur Neiva, and Belisário Penna) made during their campaigns to create a national health agency in the 1910s.

This effort, which particularly drew on observations about the disease burden on rural populations in Brazil's farthest-flung regions (which were distant from the country's political and economic centers but nonetheless threatening to the nation's health) collided with the restrictions on federal power imposed by Brazil's 1891 constitution. Hochman analyzes the campaign by a network of reformist sanitarians that led, after much debate over a range of possibilities for expanding federal public health authority, to the formation of a National Department of Public Health within the Ministry of Justice at the end of 1919. In his view, the 1918 outbreak of Spanish flu in Rio de Janeiro and São Paulo, along with epidemic yellow fever in the northeast region, helped propel this movement forward by reinforcing public health advocates' argument that states and localities are inextricably interconnected through the transmission of infectious microbes.

The subsequent chapters examine how states responded to new opportunities for cooperation with federal health authorities in combating infectious disease, particularly in rural areas where most had implemented little to no public health apparatus. In keeping with the fundamental federalist structure of Brazil's First Republic, individual states were presented with several options which allowed them to voluntarily choose the most beneficial tradeoff between autonomy and access to external resources. These resources, in the form of funding and expertise, came from both the federal government and the International Health Board of the US-based Rockefeller Foundation. As states accepted external assistance - and the consequent loss of autonomy in determining how to deal with the health of their populations - federal power increased throughout much of Brazil's interior. In this way, Hochman argues, public health concerns became a wedge to combat the disunity that characterized the Brazilian Republic overall.

Hochman ends his book with an analysis of São Paulo, an exception to the national picture in public health administration as in many other matters. Following the abolition of slavery, São Paulo state and many of its municipalities invested in public health to attract immigrant European laborers. Hochman traces the ways in which the paulista model influenced national public health policies, partly through the influence of Artur Neiva, who directed public health services in São Paulo during the late 1910s. Although the paulista elite cherished their autonomy and generally opposed federal assumption of state responsibilities, increasing federal authority over the nation's health on a voluntary, stateby-state basis spared São Paulo from having to provide aid directly to neighboring states that had not attended adequately to their own population's health and thus threatened paulistas with disease. 
It would be hard to overstate the importance of Hochman's scholarship for both the history of Brazilian public health and for understanding Brazil's First Republic, which is generally portrayed as a period of intense federalism. Hochman tempers that depiction through his analysis of one realm in which federal authority expanded despite the primary commitment to state autonomy. His somewhat schematic approach invites more detailed examination of the local contexts in which these developments unfolded, and the ideologies and personalities of the individuals involved - a task which various historians have taken up over the last two decades. His research is also heavily dependent on documentary sources in Rio de Janeiro and São Paulo; more work remains to understand public health concerns and governance beyond this corridor. Nonetheless, this clearly translated Englishlanguage edition will encourage historians of other regions to consider the implications of the early twentieth-century Brazilian case for the relationship between contagious disease and government authority elsewhere. It is a welcome addition to libraries across the Anglophone world.

\section{REFERENCES}

HOCHMAN, Gilberto.

The sanitation of Brazil: nation, state, and public

health, 1889-1930. Trans. Diane Grosklaus

Whitty. Urbana: University of Illinois Press.

2016. 